\title{
Energy exchangers with LCT as a precision method for diet control in LCHADD
}

\author{
Renata Mozrzymas ${ }^{1}$ A-D , Klaudia Konikowska ${ }^{2, A-D}$, Bożena Regulska-Ilow 2, E, F \\ ${ }^{1}$ Regional Specialist Hospital in Wrocław, Research and Development Center, Poland \\ ${ }^{2}$ Department of Dietetics, Wroclaw Medical University, Poland \\ A - research concept and design; $\mathrm{B}$ - collection and/or assembly of data; $\mathrm{C}$ - data analysis and interpretation; \\ $\mathrm{D}$ - writing the article; $\mathrm{E}$ - critical revision of the article; $\mathrm{F}$ - final approval of article
}

Address for correspondence

Klaudia Konikowska

E-mail:klaudia.konikowska@gmail.com

Funding sources

None declared

Conflict of interest

None declared

Received on December 15, 2015

Revised on February 03, 2016

Accepted on March 10, 2016

\begin{abstract}
Long-chain 3-hydroxyacyl-CoA dehydrogenase deficiency (LCHADD) is a rare genetic disease. The LCHADD treatment is mainly based on special diet. In this diet, energy from long-chain triglycerides (LCT) cannot exceed 10\%, however energy intake from the consumption of medium-chain triglycerides (MCTS) should increase. The daily intake of energy should be compatible with energy requirements and treatment should involve frequent meals including during the night to avoid periods of fasting. In fact, there are no recommendations for total content of LCT in all of the allowed food in the LCHADD diet. The aim of the study was to present a new method of diet composition in LCHADD with the use of blocks based on energy exchangers with calculated LCT content. In the study, the diet schema was shown for calculating the energy requirements and LCT content in the LCHADD diet. How to create the diet was also shown, based on a food pyramid developed for patients with LCHADD. The blocks will make it possible, in a quick and simple way, to create a balanced diet which provides adequate energy value, essential nutrients and LCT content. This method can be used by doctors and dietitians who specialize in treating rare metabolic diseases. It can also be used by patients and their families for accurate menu planning with limited LCT content.
\end{abstract}

Key words: diet, long-chain 3-hydroxyacyl-CoA dehydrogenase deficiency (LCHADD), long-chain triglycerides (LCT), intake of energy

D0I

$10.17219 /$ acem/62132

\section{Copyright}

Copyright by Author(s)

This is an article distributed under the terms of the

Creative Commons Attribution Non-Commercial License

(http://creativecommons.org/licenses/by-nc-nd/4.0/) 
LCHADD (long-chain 3-hydroxyacyl-CoA dehydrogenase deficiency) is a rare genetic disease, inherited in an autosomal recessive pattern. The disease is caused by 3-hydroxyacyl-CoA dehydrogenase deficiency, an enzyme complex taking part in mitochondrial $\beta$-oxidation of fatty acids. ${ }^{1}$ Deficiency of the enzyme contributes to accumulation of toxic metabolites which can lead to metabolic decompensation, associated with damage to the mechanisms of the body homeostasis. This results in the occurrence of life-threatening disorders in the functioning of one or more organs. Symptoms of metabolic decompensation are: myopathy, cardiomyopathy, hepatitis, peripheral neuropathy and retinitis pigmentosa, as well as hypoketotic hypoglycemia. ${ }^{2,3}$ Clinical symptoms result from a significant reduction in energy production in the long-chain triglycerides (LCT), the toxic effects of carnitine acyl derivatives and the incidence of hypoglycemia. ${ }^{4}$ These symptoms occur or worsen due to dietary mistakes and in a time of increased catabolism during a course of fasting, an infectious disease, stress or vaccinations. ${ }^{5}$

It is estimated that in Poland about 400 newborns are born each year with metabolic defects. ${ }^{6}$ The expected incidence of LCHADD in Poland is around 1 in 120,000 newborns. It most frequently occurs in Pomeranian Voivodeship (1 in 16,900 births). ${ }^{7}$ Since 2014 , testing aimed at detection of 21 inborn metabolic defects, including LCHADD, has been applied to all newborns in Poland. ${ }^{8}$ Presently, thanks to neonatal screening, it is possible to diagnose the disease in children before symptoms occur. In this case, application of the appropriate pharmacological and dietary treatment prevents or reduces the risk of the occurrence of clinical symptoms of the disease, its complications and sudden death.

Table 1. Estimated rest periods between meals depending on the age of children with LCHADD 5

\begin{tabular}{|c|c|c|}
\hline \multirow{2}{*}{ Age } & \multicolumn{2}{|c|}{ Rest periods between meals } \\
\hline & break per day & break per night \\
\hline Infants & $3 \mathrm{~h}$ & night feeding ${ }^{2}$ \\
\hline$<6$ months & $4 \mathrm{~h}$ & night feeding ${ }^{2}$ \\
\hline$>6$ months $^{1}$ & $4 \mathrm{~h}$ & $6-8 h^{3}$ \\
\hline$>12$ months $^{1}$ & $4 h$ & $10-12 h$ \\
\hline
\end{tabular}

${ }^{1}$ For each age group, a break in the night feeding is estimated. In children with the risk of complications, the interval should be shorter and individualized.

${ }^{2}$ In properly fed infants, fasting during the night may be extended up to $6 \mathrm{~h}$ from 3 months of age.

${ }^{3}$ In properly fed infants, fasting during the night may be extended up to $8 \mathrm{~h}$ from 6 months of age.

\section{The purpose of the study}

The aim of the study is to present a new method for preparing the menu in LCHADD using blocks based on energy exchangers with calculated LCT content. Currently, there are no dietary computer programs or scientific studies determining the total amount of LCT in all products allowed in the LCHADD diet. Patients should not have the option of self-modifying their own diet because of the probability of making mistakes. Blocks will allow a faster and easier way to prepare a balanced menu in terms of energy value and essential nutrients, as well as the LCT content in the diet.

\section{Nutrition in LCHAD deficiency}

Patients with LCHADD require application of a recommended dietary caloric intake with limited LCT.

\section{Energy requirements}

In patients with LCHADD, it is important that the energy nutrient intake from the diet is correct and fasting is avoided by taking frequent meals, including at night, especially in the infancy period and during infection. ${ }^{9,10}$ On the other hand, a large energy nutrient supply is also unfavorable as it leads to development of overweight and obesity in patients. ${ }^{9}$

Table 2. The energy requirements for healthy infants in the first year of life ${ }^{14}$

\begin{tabular}{c|c|c|c}
\multicolumn{2}{c|}{ Boys } & \multicolumn{2}{c}{ Girls } \\
\hline \multirow{2}{*}{ age } & $\begin{array}{c}\text { daily energy } \\
\text { requirement } \\
\text { (months) }\end{array}$ & $\begin{array}{c}\text { age } \\
\text { (months) }\end{array}$ & $\begin{array}{c}\text { daily energy } \\
\text { requirement } \\
(\mathrm{kcal} / \mathrm{kg} / \mathrm{d})\end{array}$
\end{tabular}

\begin{tabular}{|c|c|c|c|}
\hline $0-1$ & 113 & $0-1$ & 107 \\
\hline $1-2$ & 104 & $1-2$ & 101 \\
\hline $2-3$ & 95 & $2-3$ & 94 \\
\hline $3-4$ & 82 & $3-4$ & 84 \\
\hline $4-5$ & 81 & $4-5$ & 83 \\
\hline $5-6$ & 81 & $5-6$ & 82 \\
\hline $6-7$ & 79 & $6-7$ & 78 \\
\hline $7-8$ & 79 & $7-8$ & 78 \\
\hline $8-9$ & 79 & $8-9$ & 78 \\
\hline $9-10$ & 80 & $9-10$ & 79 \\
\hline $10-11$ & 80 & $10-11$ & 79 \\
\hline $11-12$ & 81 & $11-12$ & 79 \\
\hline
\end{tabular}


Table 1 presents estimated rest periods between meals depending on the age of children with LCHADD, as developed by Spiekerkoetter et al. ${ }^{5}$ The authors recommend that in states of exacerbation, rest periods between meals should be shorter.

Energy requirements should be set individually for each patient with LCHADD, taking into account age, weight, height and physical activity. ${ }^{11}$ In determining the energy requirements in the LCHADD diet it is recommend that Polish norms or rules on the nutrition of children and adults are used, taking into account the recommendations of the World Health Organization (WHO). ${ }^{12-14}$ Table 2 shows the energy requirements for healthy infants in the first year of life while Table 3 shows the energy needs for healthy children between 1 and 10 years of age according to the WHO. ${ }^{14}$ Table 4 presents the energy requirements for healthy adults with moderate physical activity developed on the basis of Polish norms. ${ }^{12}$

Although the daily energy requirements given in the standards and recommendations are determined for
Table 3. The energy requirements for healthy children between 1 and 10 years of age ${ }^{14}$

\begin{tabular}{|c|c|c|c|c|c|}
\hline \multicolumn{3}{|c|}{ Boys } & \multicolumn{3}{|c|}{ Girls } \\
\hline $\begin{array}{c}\text { age } \\
\text { (months) }\end{array}$ & $\begin{array}{l}\text { weight } \\
(\mathrm{kg})\end{array}$ & $\begin{array}{l}\text { daily energy } \\
\text { requirement } \\
(\mathrm{kcal} / \mathrm{kg} / \mathrm{d})\end{array}$ & $\begin{array}{c}\text { age } \\
\text { (months) }\end{array}$ & $\begin{array}{c}\text { weight } \\
(\mathrm{kg})\end{array}$ & $\begin{array}{l}\text { daily energy } \\
\text { requirement } \\
\text { (kcal/kg/d) }\end{array}$ \\
\hline $1-2$ & 11.5 & 82.4 & $1-2$ & 10.8 & 80.1 \\
\hline $2-3$ & 13.5 & 83.6 & $2-3$ & 13.0 & 80.6 \\
\hline $3-4$ & 15.7 & 79.7 & $3-4$ & 15.1 & 76.5 \\
\hline $4-5$ & 17.7 & 76.8 & $4-5$ & 16.8 & 73.9 \\
\hline $5-6$ & 19.7 & 74.5 & $5-6$ & 18.6 & 71.5 \\
\hline $6-7$ & 21.7 & 72.5 & $6-7$ & 20.6 & 69.3 \\
\hline $7-8$ & 24.0 & 70.5 & $7-8$ & 23.3 & 66.7 \\
\hline $8-9$ & 26.7 & 68.5 & $8-9$ & 26.6 & 63.8 \\
\hline $9-10$ & 29.7 & 66.6 & $9-10$ & 30.5 & 60.8 \\
\hline
\end{tabular}

Table 4. The energy requirements for healthy adults with a moderate physical activity $(P A L=1.6)^{12}$

\begin{tabular}{|c|c|c|c|c|c|}
\hline \multicolumn{3}{|c|}{ Boys } & \multicolumn{3}{|c|}{ Girls } \\
\hline $\begin{array}{c}\text { age } \\
\text { (years) }\end{array}$ & $\begin{array}{c}\text { weight } \\
(\mathrm{kg})\end{array}$ & $\begin{array}{l}\text { daily energy } \\
\text { requirement } \\
(\mathrm{kcal} / \mathrm{d})\end{array}$ & $\begin{array}{c}\text { age } \\
\text { (years) }\end{array}$ & $\begin{array}{l}\text { weight } \\
\text { (kg) }\end{array}$ & $\begin{array}{l}\text { daily energy } \\
\text { requirement } \\
(\mathrm{kcal} / \mathrm{d})\end{array}$ \\
\hline \multirow{3}{*}{ 19-30 } & 60 & 2600 & \multirow{3}{*}{ 19-30 } & 50 & 2000 \\
\hline & 70 & 2800 & & 60 & 2200 \\
\hline & 80 & 3100 & & 70 & 2650 \\
\hline \multirow{3}{*}{$31-50$} & 60 & 2500 & \multirow{3}{*}{$31-50$} & 50 & 2000 \\
\hline & 70 & 2700 & & 60 & 2100 \\
\hline & 80 & 2800 & & 70 & 2250 \\
\hline \multirow{3}{*}{$51-65$} & 60 & 2300 & \multirow{3}{*}{$51-65$} & 50 & 1900 \\
\hline & 70 & 2450 & & 60 & 2000 \\
\hline & 80 & 2550 & & 70 & 2100 \\
\hline
\end{tabular}
healthy people, these values can be used for preparing a diet for patients with LCHADD, including monitoring the energy supply from the diet and the patient's health and controlling body weight.

\section{The structure of the diet}

The optimal LCHADD diet is considered to be norm-caloric, norm-protein and high-carbohydrate with a limited content of LCT - up to $10 \%$ of the energy nutrient intake in daily food rations. ${ }^{9,13}$ Due to the reduced percentage of LCT in the diet, the intake of medium chain fatty acids (medium-chain triglycerides, MCT) should be increased up to $10-25 \%$. The appropriate distribution of the meals throughout the day should also be taken into account (Table 1).

In the case of overweight and obesity in children with LCHADD, a higher intake of protein and a proportional reduction in the calorie intake from carbohydrates is recommended in order to maintain proper metabolic balance., ${ }^{9,15}$ Gillingham et al. observed a positive impact of higher protein intake in the diet on energy balance and metabolic control in patients with LCHADD. ${ }^{15}$ However, more studies are needed to confirm these observations. Table 5 shows the structure of the diet in LCHADD developed on the basis of the current scientific findings.

\section{MCT oil}

In the treatment of LCHADD, the use of MCT oil reduces the risk of catabolism caused by peri- 
Table 5. Estimated energy structure of the diet in LCHADD developed on the basis of the current scientific findings $5,13,15,24,2$.

\begin{tabular}{|c|c|c|c|c|}
\hline \multicolumn{3}{|c|}{$\begin{array}{c}\text { Protein } \\
\text { (\% total energy intake) }\end{array}$} & \multicolumn{2}{|c|}{$12-15 \% *$} \\
\hline \multicolumn{3}{|c|}{$\begin{array}{c}\text { Carbohydrate } \\
\text { (\% total energy intake) }\end{array}$} & \multicolumn{2}{|c|}{$60-67 \% *$} \\
\hline \multicolumn{3}{|c|}{$\begin{array}{c}\text { Fat } \\
\text { (\% total energy intake) }\end{array}$} & \multicolumn{2}{|c|}{$20-30 \%$} \\
\hline \multirow{4}{*}{$\begin{array}{c}\text { MCT10 - } \\
15 \% \\
\text { of energy } \\
\text { intake }\end{array}$} & \multicolumn{4}{|c|}{ LCT 5 - 10\%. of energy intake including: } \\
\hline & \multicolumn{2}{|c|}{$\mathrm{DHA}$} & \multicolumn{2}{|c|}{ NNKT 1-4 \% } \\
\hline & $\begin{array}{l}\text { weight } \\
<20 \mathrm{~kg}\end{array}$ & $\begin{array}{l}\text { weight } \\
>20 \mathrm{~kg}\end{array}$ & $\begin{array}{l}\text { LA (C18:2; } \\
\text { omega-6) }\end{array}$ & $\begin{array}{l}\text { ALA (C18:3; } \\
\text { omega - 3) }\end{array}$ \\
\hline & $60 \mathrm{mg} / \mathrm{d}$ & $120 \mathrm{mg} / \mathrm{d}$ & $2-4 \%$ & $\sim 0.5 \%$ \\
\hline
\end{tabular}

*Some authors suggest a higher intake of protein and a proportional reduction in the calorie intake from carbohydrates in patients who have problems with maintaining a healthy weight.

ods of fasting, and has a beneficial effect on improving the fatty acids profile and acylcarnitine concentration in the blood. ${ }^{9}$ The MCT oil should cover $10-20 \%$ of the daily caloric intake. ${ }^{13}$ The study of Gillingham et al. in children with LCHAD deficiency whose caloric intake of LCT was $\leq 10 \%$ of the total calories in daily food rations and the intake of MCT was $\geq 10 \%$ of the calories in daily food rations, indicated lower concentrations of the toxic acyl derivatives of carnitine. ${ }^{16}$

Medium chain fatty acids play an important role during physical effort in patients with LCHADD and can provide an alternative source of energy for muscular work. Insufficient calorie intake both before and during doing physical exercise can lead to cardiomyopathy and rhabdomyolysis. ${ }^{17,18}$ Some authors suggest that supplementation of MCT with a dose of $0.5 \mathrm{~g}$ per $\mathrm{kg}$ of the non-fat body mass during increased physical activity can prevent the occurrence of metabolic disorders in children with LCHADD. ${ }^{9}$ A study by Gillingham et al. demonstrated that supply of MCT immediately before exercise improved exercise tolerance and reduced the risk of rhabdomyolysis in 6 out of 10 patients with disorders of fatty acid oxidation disorders (FAODs) ${ }^{19}$ A study by Behrendt et al. indicated that the intake of MCT before doing exercise increased medium chain fatty acid oxidation, caused a reduction in glucose oxidation and a reduction of the burden on the heart during exercise in 8 of 11 patients with LCHADD, compared to providing exclusively carbohydrates. ${ }^{17}$ However, the study's authors point out that, in practice, MCT intake (0.3-0.4 per $\mathrm{kg}$ ) before physical effort contributes to their greater use, especially when the MCT are given with a beverage containing carbohydrates. This allows patients with FAODs to safely perform the training for up to one hour of moderate intensity (60-70\% of maximum heart rate, HRmax).
An example of food for a special medical purpose (FSMP) which can be administered prior to the scheduled physical effort is MCT Procal. 1 portion (16 g) provides $105 \mathrm{kcal}, 10 \mathrm{~g}$ of MCT and $0.14 \mathrm{~g}$ of LCT. ${ }^{20}$ Fantomalt is an example of a FSMP containing a mixture of carbohydrates in which the complex ones constitute $90 \%$. Three measuring spoons of this preparation $(3 \times 5 \mathrm{~g})$ provide $57 \mathrm{kcal}$. Fantomalt in its composition consists mainly of maltodextrin with less maltose and glucose. The preparation can be diluted with water or juice or added to a ready dish. The number of portions of these FSMP should be selected individually for each patient depending on their physical activity.

\section{Linoleic acid (LA, C18:2, omega-6) and a-linolenic acid (ALA, C18:3, omega-3)}

Adequate intake of fatty acids LA and ALA with the diet is particularly important and should be included in the total consumption of LCT with the diet. LA and ALA prevent diseases of the retina, peripheral neuropathy, growth deficit and dermatitis., ${ }^{9} 13$ According to the recommendations made by the European Food Safety Authority (EFSA) of 2013, the demand for fatty acids LA and ALA in healthy children up to 12 months of age, is 4 and $0.5 \%$ of the total energy intake, respectively. ${ }^{21,22}$ However, according to the recommendations of German, Austrian and Swiss Experts (DACH), intake of LA with the diet for children over 4 months of age up to 12 months of age should constitute $3.5 \%$ of the energy requirements. In the diet of children between 1 and 4 years of age and between 4 and 10 years of age the intake of LA should constitute $3 \%$ and $2.5 \%$ of the total energy requirements, respectively. ${ }^{23}$ Because of the risk of deficiency of essential fatty acids (EFA), their intake in the diet in LCHADD should be similar to the dietary intake of healthy children and adults. However, some authors suggest that the supply of essential fatty acids in patients with LCHADD should be from 1 to $2 \%$ of the total energy intake, and their main source from food should be vegetable oils, such as linseed oil, rapeseed oil, walnut oil, and safflower oil. ${ }^{24-26}$

The use of linseed oil, camelina oil or walnut oil, in comparison with rapeseed oil may reduce the accumulation of the various acyl-CoA intermediates, preventing peripheral neuropathy. ${ }^{9}$ Spiekerkoetter et al. recommend the use of walnut oil, soybean oil or wheat germ oil for an optimal ratio of omega- 6 to omega- $3 .{ }^{5}$ However, in the studies of Charles et al. in patients with the $\beta$-oxidation of fatty acids disorder, it has been indicated that the combination of linseed oil and walnut oil is more favorable than rapeseed oil. ${ }^{27}$ It is associated with a higher proportion of essential fatty acids (EFAs) in linseed oil and walnut oil, compared to rapeseed oil. Table 6 presents the recommended daily dose of the vegetable oils mentioned above, depending on the age of the patient. Table 7 shows the contents of LA, ALA and LCT in vegetable oils and lin- 
Table 6 . The recommended daily amount of vegetable oils such as soybean oil, wheat germ oil and walnut oil, depending on the age of the patient ${ }^{5}$

\begin{tabular}{|c|c|}
\hline The patient's age & Portion of oil $[\mathrm{g} / \mathrm{d}]$ \\
\hline $0-4$ months & 3.5 \\
\hline $4-12$ months & 5.0 \\
\hline $1-4$ years & 6.0 \\
\hline 4 years & 10.0 \\
\hline
\end{tabular}

seeds in one energy exchanger $(1 \mathrm{EE} \approx 50 \mathrm{kcal}$, discussed later in the paper).

In connection with the recommendations concerning adequate dietary intake of essential fatty acids in LCHADD, the market offers food for special medical purposes, which in their composition in addition to MCT also contain EFAs, e.g. Lipistart. ${ }^{28}$

\section{Supplementation with DHA acids}

Opinions regarding the dietary intake of DHA in LCHADD are divided. Some authors recommend DHA acid as a dietary supplement, due to its negligible dietary intake with the intake in the diet with limited LCT. In the research studies of Gillingham et al. of children with LCHADD $(n=14)$, the only source of DHA in the diets were dietary supplements. ${ }^{16}$

Supplementation with DHA ethyl esters, about $100 \mathrm{mg} /$ day can be considered, due to the possibility of improving visual acuity. ${ }^{9}$ Spiekerkoetter et al. recommend dietary supplementation with DHA at a dose of $60 \mathrm{mg}$ per day for children weighing less than $20 \mathrm{~kg}$ and $120 \mathrm{mg}$ per day for children weighing more than $20 \mathrm{~kg} .{ }^{5}$

\section{Cornstarch}

The use of raw corn starch in the diet of patients with LCHADD reduces the risk of nocturnal fasting. ${ }^{9}$ Consumption of raw starch before bedtime prevents the morning hypoglycemia after an overnight break in nutrition. ${ }^{9,24}$ Corn starch in the diet of children with LCHADD below 2 years of age is recommended in doses of 1-1.5 g per $\mathrm{kg}$ of body mass. At the age of 2 years of age, the dose is gradually increased (1.75-2.5 g per kg of body mass). ${ }^{9,24,25,29}$

Spiekerkoetter et al. believe that routine enriching of the diet with corn starch and glucose polymers is not recommended, yet may be a part of an oral prophylaxis and treatment in emergency cases related to the risk of clinical symptoms caused by too long a night break. ${ }^{5}$ The oral intake of raw corn starch is not recommended for infants less than 9 months of age, due to the insufficient action of pancreatic enzymes. ${ }^{30}$

\section{Carnitine supplementation}

For patients with carnitine deficiency, supplementation of carnitine may be considered. ${ }^{9}$ Gillingham et al. found no sign of toxicity during application of carnitine at a dose of $50 \mathrm{mg}$ per $\mathrm{kg}$ of body mass. ${ }^{24}$ However, there is no published data concerning the potential benefits of supplementation with long term carnitine in LCHADD. It is forbidden to use it during acute metabolic decompensation. ${ }^{5,9}$

\section{Intake of glucose intravenously}

The occurrence of metabolic decompensation in a patient with LCHADD frequently requires hospitalization and ensuring the adequate intake of glucose as an energy source. When the oral intake of carbohydrates before hospitalization does not give the expected results, the patient receives an intravenous infusion of glucose in amounts of $8-10 \mathrm{mg} / \mathrm{kg}$ of body mass $/ \mathrm{min}$. The intake

Table 7. The contents of LA, ALA, LCT and the ratio of omega- 6 to omega- 3 in vegetable oils and linseeds in one energy exchanger (1 EE $\approx 50 \mathrm{kcal}$ )

\begin{tabular}{|c|c|c|c|c|c|c|}
\hline $\begin{array}{l}\text { Grams of selected fatty acids } \\
\text { and ratio of omega- } 6 \text { to } \\
\text { omega- } 3 \text { in } 1 E E=\text { in some oils }\end{array}$ & $\begin{array}{l}\text { Flaxseed } \\
\text { oil } \\
(1 \mathrm{EE}=6.0 \mathrm{~g})\end{array}$ & $\begin{array}{l}\text { Walnuts } \\
\text { oil } \\
(1 \mathrm{EE}=6.0 \mathrm{~g})\end{array}$ & $\begin{array}{l}\text { Soybean } \\
\text { oil } \\
(1 \mathrm{EE}=6.0 \mathrm{~g})\end{array}$ & $\begin{array}{l}\text { Wheat germ oil } \\
\qquad(1 E E=6.0 \mathrm{~g})\end{array}$ & $\begin{array}{l}\text { Canola oil, cold- } \\
\text { pressed } \\
(1 \mathrm{EE}=6.0 \mathrm{~g})\end{array}$ & $\begin{array}{c}\text { Linseed } \\
(1 \mathrm{EE}=9.0 \mathrm{~g})\end{array}$ \\
\hline $1 \mathrm{EE} \approx 50 \mathrm{kcal}[\mathrm{g}]$ & $6.0^{1}$ & $6.0^{1}$ & $6.0^{1}$ & $6.0^{1}$ & $6.0^{1}$ & $9.0^{1}$ \\
\hline LA (omega-6) [g] & 0.9 & 3.2 & 2.5 & 3.3 & 1.1 & 0.5 \\
\hline ALA (omega-3) [g] & 3.2 & 0.6 & 0.4 & 0.4 & 0.6 & 2.1 \\
\hline $\mathrm{LCT}[\mathrm{g}]$ & 5.7 & 5.7 & 5.7 & 5.6 & 5.7 & 3.6 \\
\hline omega-6/omega-3 & 0.3 & 5.1 & 6.1 & 7.9 & 1.9 & 0.3 \\
\hline
\end{tabular}

$16.0 \mathrm{~g}$ of vegetable oil is about 1 teaspoon, and $9.0 \mathrm{~g}$ of flaxseed is less than 1 spoon, however in LCHADD, all food products should be weighed. 
Table 8. The energy requirements of the patient converted to the amount of energy exchangers and LCT content ( $\mathrm{g} / \mathrm{d}$ )

\begin{tabular}{|c|c|c|c|c|c|c|c|c|}
\hline \multirow{2}{*}{$\begin{array}{c}\text { Daily energy } \\
\text { requirement } \\
\text { kcal/d }\end{array}$} & \multirow{2}{*}{$\begin{array}{c}\begin{array}{c}\text { Amount } \\
\text { of } E E\end{array} \\
E E / d\end{array}$} & \multicolumn{7}{|c|}{$\begin{array}{c}\text { LCT content depend on daily energy requirement and share of dietary } \\
\text { energy consumption from LCT }(4-10 \%)\end{array}$} \\
\hline & & $4 \%$ & $5 \%$ & $6 \%$ & $7 \%$ & $8 \%$ & $9 \%$ & $10 \%$ \\
\hline 500 & 10 & 2.2 & 2.8 & 3.3 & 3.9 & 4.4 & 5.0 & 5.6 \\
\hline 600 & 12 & 2.7 & 3.3 & 4.0 & 4.7 & 5.3 & 6.0 & 6.7 \\
\hline 700 & 14 & 3.1 & 3.9 & 4.7 & 5.4 & 6.2 & 7.0 & 7.8 \\
\hline 800 & 16 & 3.6 & 4.4 & 5.3 & 6.2 & 7.1 & 8.0 & 8.9 \\
\hline 900 & 18 & 4.0 & 5.0 & 6.0 & 7.0 & 8.0 & 9.0 & 10.0 \\
\hline 1000 & 20 & 4.4 & 5.6 & 6.7 & 7.8 & 8.9 & 10.0 & 11.1 \\
\hline 1200 & 24 & 5.3 & 6.7 & 8.0 & 9.3 & 10.7 & 12.0 & 13.3 \\
\hline 1500 & 30 & 6.7 & 8.3 & 10.0 & 11.7 & 13.3 & 15.0 & 16.7 \\
\hline 1800 & 36 & 8.0 & 10.0 & 12.0 & 14.0 & 16.0 & 18.0 & 20.0 \\
\hline 2000 & 40 & 8.9 & 11.1 & 13.3 & 15.6 & 17.8 & 20.0 & 22.2 \\
\hline 2200 & 44 & 9.8 & 12.2 & 14.7 & 17.1 & 19.6 & 22.0 & 24.4 \\
\hline 2500 & 50 & 11.1 & 13.9 & 16.7 & 19.4 & 22.2 & 25.0 & 27.8 \\
\hline 2800 & 56 & 12.4 & 15.6 & 18.7 & 21.8 & 24.9 & 28.0 & 31.1 \\
\hline 3000 & 60 & 13.3 & 16.7 & 20.0 & 23.3 & 26.7 & 30.0 & 33.3 \\
\hline
\end{tabular}

of glucose stimulates insulin secretion and inhibits peripheral lipolysis. However, some patients with abnormal response to insulin should additionally be supplemented with insulin therapy without diminishing the adequate dietary intake of glucose., ${ }^{9,31}$

\section{Supplementation with vitamins and minerals}

Intake of certain vitamins and minerals in the form of dietary supplements, especially fat-soluble vitamins, is recommended in the case of low dietary intake or documented deficiency. ${ }^{5}$ It is important that fat-soluble vitamins were served with meals containing fat, in this case MCT, to be absorbed better.

\section{The method developed for dietary control in LCHADD}

LCHADD treatment is based mainly on dietary therapy. Parents or guardians of a sick child should have knowledge concerning the allowed and forbidden products. The aim of dietary therapy in LCHADD is to adequately balance the diet as regards energy values and the diet structure, i.e. adequate intake of proteins, fats and carbohydrates and the content of LCT. The available Polish studies give the nutritional value of foods and specify the composition of fatty acids in food products. However, the calculation of the sum of LCT, which is important in preparing a menu in LCHADD, has to be done independently and it is rather time consuming. ${ }^{32}$

Due to the lack of a clear and easy method for preparing the diet in LCHADD, this paper presents a new method for preparing the menu in this rare metabolic disease.

The basis for dietary calculations in LCHADD is correctly calculating the energy requirements individually for each patient. Meals should be spread evenly throughout the day and with adequate caloric content, in order to prevent a starvation period. Parents and caregivers of children with LCHADD often make dietary mistakes. The most common error, resulting from the fear of the occurrence of fasting and symptoms connected with it, is to give an excessive amount of simple carbohydrates, 
which can lead to overweight or obesity in a patient. Treatment of obesity or overweight in patients with LCHADD is difficult and may be limited due to the possibility of the occurrence of disease symptoms resulting from catabolism. In the body of a patient with LCHADD, at the time of fasting there is no production of ketone compounds, which substitute a substrate for the brain in the case of a deficiency of glucose. Therefore controlling energy intake, the LCT content in daily food rations and an appropriate diet structure in LCHADD are important elements in preventing both catabolism and obesity.

The developed block method of preparing a menu in LCHADD applies energy exchangers (EE). One energy exchanger is the weight of the product expressed in $\mathrm{g}$, which provides $50 \mathrm{kcal}(210 \mathrm{~kJ})$. LCT content was calculated with regard to the energy exchangers of various food products. The values of energy exchangers and LCT are based on data from the Polish "Tables of Composition and Nutritional Value of Food", published in $2005 .^{32}$

Energy requirements calculated as the number of energy exchangers are shown in Table 8. The dose of LCT (g/day) sufficient for energy requirements was calculated, depending on the desired LCT energy input in the diet.

In the Polish study, the total LCT value is not calculated, yet the contents of each of 26 individual fatty acids for particular food products are given. ${ }^{32}$ On the basis of the tables, LCT calculations were made by summing up the fatty-acids containing 12 and more carbon atoms in the chain in different food products. Then the LCT content in $100 \mathrm{~g}$ of food was converted into the LCT content in a portion of products including $50 \mathrm{kcal}$.

Safe products which can be used in the diet in LCHADD were regarded to be all the products in which the LCD content does not exceed $2 \mathrm{~g}$ in $100 \mathrm{~g}$. Other products have been conventionally classified as hazardous. Unsafe products are marked in red, and some of them are presented in the form of blocks as some of them may be used in limited and controlled amounts in the LCHADD diet, e.g. linseed oil, walnut oil, soybean oil and beef.

Selection of food products allowed in LCHAD deficiency is important due to the proper balance of the diet in terms of the caloric content, LCT input in daily food

Table 9. Description of blocks in the developed method in LCHADD

\begin{tabular}{|c|c|c|c|}
\hline Number of blocks & Type of blocks & Description of blocks & Block color \\
\hline 1,2 & $\begin{array}{l}\text { medical: - MCT milk, } \\
\text { MCT oil, - mixture of } \\
\text { carbohydrate }\end{array}$ & food for special medical purposes for use under medical supervision & $\begin{array}{l}\text { light blue (doctor's or } \\
\text { dietitian's face } \\
\text { on block) }\end{array}$ \\
\hline 3 & emergency & food products with high energy density and small amount of LCT & gold \\
\hline 4,5 & allowed & food products which do not contain LCT & dark green \\
\hline 6 & meat & \multirow{3}{*}{$\begin{array}{l}\text { food products which contain safe amount of LCT } \\
\text { and are good source of protein }\end{array}$} & \multirow{5}{*}{ white } \\
\hline 7 & fish & & \\
\hline 8 & dairy $\leq 0.5 \%$ fat & & \\
\hline 9 & bread & \multirow{2}{*}{$\begin{array}{l}\text { food products which contain safe amount of LCT and are good } \\
\text { source of protein and carbohydrates }\end{array}$} & \\
\hline 10 & other grain products & & \\
\hline $11,12,13$ & fruits & fresh fruits which contain safe amount of LCT & yellow \\
\hline 14,15 & fruits, emergency & $\begin{array}{l}\text { dried fruits, jam, marmalade and fruit syrops containing a small } \\
\text { amount of LCT }\end{array}$ & orange \\
\hline $16,17,18,19,20$ & vegetables & mainly fresh vegetables & $\begin{array}{l}\text { green } \\
\text { dark blue }\end{array}$ \\
\hline 21 & spice & $\begin{array}{l}\text { spicy vegetables (e.g. garlic) and processed products (e.g. ketchup) } \\
\text { giving the dishes more intense flavor }\end{array}$ & pink \\
\hline 22 & LCT bombs - vegetable oils & $\begin{array}{l}\text { vegetable oils which are source of EFAs and containing } \\
\text { a lot amount of LCT }\end{array}$ & \multirow{2}{*}{$\begin{array}{l}\text { red - amount of food } \\
\text { products in this group } \\
\text { is very limited }\end{array}$} \\
\hline 23 & LCT bombs - meat & $\begin{array}{l}\text { beef, veal, turkey and variety meats containing a lot of LCT which are } \\
\text { good source of certain nutrients (eg. vitamin B12) }\end{array}$ & \\
\hline 24,25 & sports & $\begin{array}{l}\text { the blocks defining the various sport activities and their } \\
\text { energy expenditure (- EE) }\end{array}$ & black \\
\hline
\end{tabular}


Table 10. The energy expenditure (-EE) of various physical activities calculated for a person weighing about $60 \mathrm{~kg}^{33,34}$

\begin{tabular}{|c|c|c|c|}
\hline \multicolumn{2}{|r|}{ Type of physical activity } & $\begin{array}{l}\text { Energy expenditure } \\
\mathrm{kcal} / \mathrm{h}\end{array}$ & $\begin{array}{l}\text { Energy expenditure } \\
50 \mathrm{kcal} \text { [min] }\end{array}$ \\
\hline & Tennis & 204 & 15 \\
\hline & Baseball & 247 & 12 \\
\hline & Cycling & 264 & 11 \\
\hline & Lawn tennis & 365 & 8.5 \\
\hline & Canoeing $6 \mathrm{~km} / \mathrm{h}$ & 370 & 8.5 \\
\hline & Walk 4 km/h & 172 & 17.5 \\
\hline & March $6 \mathrm{~km} / \mathrm{h}$ & 257 & 12 \\
\hline & Playing football & 471 & 6.5 \\
\hline & Mountain climbing & 529 & 6 \\
\hline \multirow{7}{*}{ Running } & run $9 \mathrm{~km} / \mathrm{h}$ & 540 & 6 \\
\hline & cross country running & 587 & 5 \\
\hline & run $11 \mathrm{~km} / \mathrm{h}$ (on a treadmill) & 736 & 4 \\
\hline & long-distance running & 793 & 4 \\
\hline & run 14 km/h (on a treadmill) & 818 & 3.5 \\
\hline & run $18 \mathrm{~km} / \mathrm{h}$ (on a treadmill) & 1036 & 3 \\
\hline & run (sprint) & 1985 & 1.5 \\
\hline
\end{tabular}

Fig. 1. Food pyramid for patients with LCHADD for 1500 kcal (30 EE)

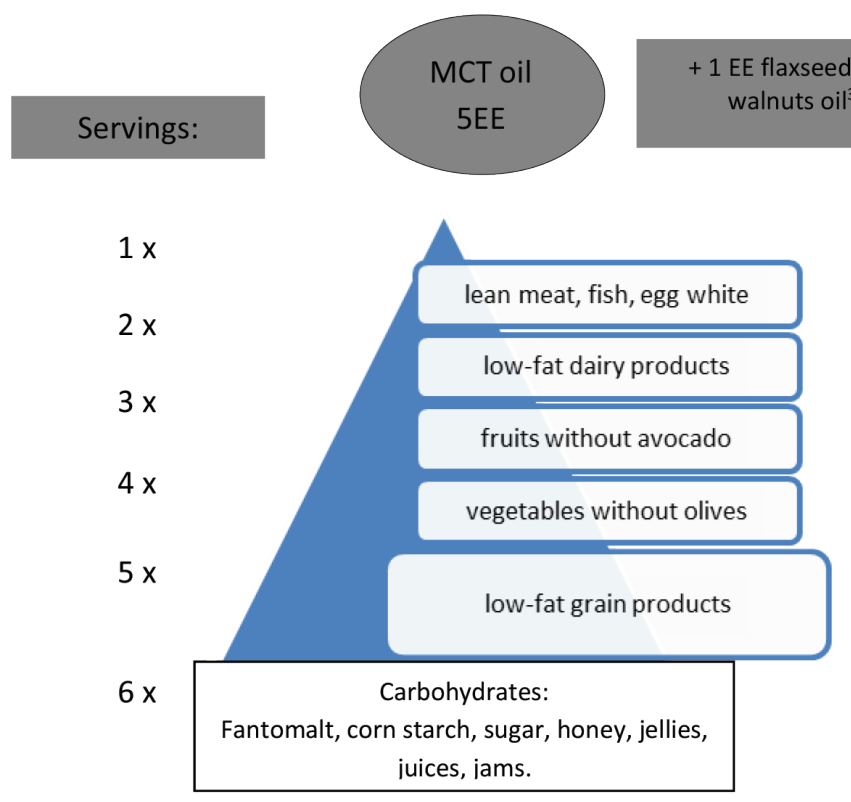

+ Humana with MCT or Lipistart rations and proper diet structure. Blocks created based on EE and LCT content are assigned to the appropriate groups of food products according to the nutrition pyramid in LCHADD (Fig. 1). Food products are situated on 5 walls rows of blocks and the LCT content in energy exchangers is given. Each block is positioned with a drawing on its upper surface, and adjusted to a given group of food products. 23 food blocks and 2 sports blocks have been developed in the new method. A description of the blocks is presented in Table 9.

In the sports blocks the concept of energy expenditure (-EE) has been introduced, which is defined as the amount of energy expended by the human body during a given activity at a certain time. One energy expenditure (-EE) is the amount of time the activity is done expressed in min and $\mathrm{s}$, which corresponds to the energy expenditure of $50 \mathrm{kcal}(210 \mathrm{~kJ})$. In contrast to energy exchangers, the shortcut of energy expenditure has a minus sign, and all the squares of energy expenditure are marked in black. Each side of the square in the sports block shows the energy expenditure of $50 \mathrm{kcal}(210 \mathrm{~kJ})$. Energy expenditures were calculated for a person weighing about $60 \mathrm{~kg}$. Table 10 shows the energy expenditure of various physical activities. $^{33,34}$

Adequate increase of caloric content of the diet in LCHADD in relation to the planned additional vigorous exercise is one of the basic elements of the diet to prevent metabolic decompensation. For this purpose, the relevant measures of specific nutritional purposes with MCT are used and should necessarily be administered before and during exercise. Sports blocks in the form of energy expenditure will allow a quick way to determine if the daily

${ }^{1}$ It can use more EE from low-fat dairy products or lean meat, fish and egg white whereas the amount of food for a special medical purpose (FSMP), like Humana with MCT or Lipistart, should be proportionally reduced. ${ }^{2}$ It can use more EE from low-fat grain products whereas the amount of carbohydrate-containing foods should be proportionally reduced.

${ }^{3}$ Flaxseed oil or walnut oil should not be used during acute metabolic decompensation. 
Table 11. Nutrition plan for 6-year-old patient with LCHADD (1500 kcal = 30EE)

\begin{tabular}{|c|c|c|c|c|c|}
\hline \multirow{2}{*}{ Time of meal } & \multirow{2}{*}{ Food product } & \multicolumn{3}{|c|}{ Energy exchangers } & \multirow{2}{*}{ Food preparation } \\
\hline & & EE & serving & LCT & \\
\hline \multirow{7}{*}{ 7:00 } & wheat flour type 500 & 1 & $15 \mathrm{~g}$ & $0.17 \mathrm{~g}$ & \multirow{7}{*}{$\begin{array}{l}\text { Mix quark fresh cheese with egg white, flour and MCT } \\
\text { oil and then blend it. Fry pancakes on a frying pan for } \\
\text { pancakes. Pour honey over pancakes. Prepare apple } \\
\text { juice with flaxseed oil to drink (blend flaxseed oil with } \\
\text { orange juice). } \\
\text { *Instead of using } 6 \mathrm{~mL} \text { flaxseed oil, you can use } 3 \mathrm{~mL} \\
\text { walnuts oil and } 3 \mathrm{~mL} \text { flaxseed oil. }\end{array}$} \\
\hline & egg white & $1 / 2$ & $26 \mathrm{~g}$ & - & \\
\hline & $\begin{array}{l}\text { quark fresh cheese, } \\
\text { low-fat }\end{array}$ & 1 & $51 \mathrm{~g}$ & $0.21 \mathrm{~g}$ & \\
\hline & honey & $1 / 2$ & $7.5 \mathrm{~g}$ & - & \\
\hline & MCT oil & 1 & $6 \mathrm{~mL}$ & - & \\
\hline & orange juice & $13 / 4$ & $204 \mathrm{~g}$ & $0.21 \mathrm{~g}$ & \\
\hline & flaxseed oil* & 1 & $6 \mathrm{~mL}$ & $5.7 \mathrm{~g}$ & \\
\hline $8: 00$ & apple & 1 & $109 \mathrm{~g}$ & $0.15 \mathrm{~g}$ & An apple between meals. \\
\hline \multirow{5}{*}{$10: 30$} & semolina & 1 & $14 \mathrm{~g}$ & $0.13 \mathrm{~g}$ & \multirow{5}{*}{$\begin{array}{l}\text { To boiling milk (approx. } 120 \mathrm{~mL} \text { ) with water (approx. } 50 \\
\mathrm{~mL} \text { ) add semolina and stir thoroughly for several min. } \\
\text { Pour porridge into a bowl. Cut orange into small pieces } \\
\text { and add it to semolina. Also add a pinch of cinnamon } \\
\text { or pinch of gingerbread spice and honey. Humana with } \\
\text { MCT to drink. }\end{array}$} \\
\hline & milk, $0.5 \%$ fat & 1 & 128 & $0.51 \mathrm{~g}$ & \\
\hline & orange & $1 / 2$ & $57 \mathrm{~g}$ & $0.06 \mathrm{~g}$ & \\
\hline & honey & $1 / 2$ & $7.5 \mathrm{~g}$ & - & \\
\hline & Humana with MCT & 1 & $11 \mathrm{~g}$ & $0.73 \mathrm{~g}$ & \\
\hline \multirow{6}{*}{$14: 00$} & celery & $1 / 4$ & $59.5 \mathrm{~g}$ & $0.09 \mathrm{~g}$ & \multirow{6}{*}{$\begin{array}{l}\text { Cream soup of white vegetables: peel and cube } \\
\text { vegetables to small pieces. Put the pieces of celery and } \\
\text { parsley root into the pot with hot MCT oil. Fry them } \\
\text { for about } 2 \text { min then add water (approx. } 300 \mathrm{~mL} \text { ) and } \\
\text { spices (salt, pepper, allspice, bay leaf). After } 15 \text { min add } \\
\text { the pieces of turnip and cauliflower, cook for another } \\
20-25 \text { min, until vegetables are tender. Remove allspice } \\
\text { and bay leaf. Blend the soup to a smooth cream, add } \\
\text { spices (e.g. a pinch of nutmeg). To prepare cream add } \\
\text { toast bread, prepared earlier on a dry frying pan. }\end{array}$} \\
\hline & turnip & $1 / 4$ & $48 \mathrm{~g}$ & $0.10 \mathrm{~g}$ & \\
\hline & parsley root & $1 / 2$ & $66 \mathrm{~g}$ & $0.24 \mathrm{~g}$ & \\
\hline & cauliflower & $1 / 4$ & $57 \mathrm{~g}$ & $0.08 \mathrm{~g}$ & \\
\hline & plain bread & 1 & $20 \mathrm{~g}$ & $0.27 \mathrm{~g}$ & \\
\hline & MCT oil & 1 & $6 \mathrm{~mL}$ & - & \\
\hline \multirow{5}{*}{$15: 30$} & $\operatorname{cod}$ & $11 / 4$ & $80 \mathrm{~g}$ & $0.35 \mathrm{~g}$ & \multirow{5}{*}{$\begin{array}{l}\text { Cook white rice in salted water, add two pinches of } \\
\text { curcumin to the rice. Season cod with pepper, brush } \\
\text { each side of the cod with MCT oil by using a pastry } \\
\text { brush. Fry the cod on a hot grill pan about } 3 \text { min on } \\
\text { each side, then add salt. Cook broccoli and serve with } \\
\text { yoghurt and MCT oil ( } 6 \mathrm{~mL} \text { ) or blend broccoli with } \\
\text { yoghurt and MCT oil }(6 \mathrm{~mL}) \text {. Water to drink. }\end{array}$} \\
\hline & white rice & 2 & $30 \mathrm{~g}$ & $0.18 \mathrm{~g}$ & \\
\hline & broccoli & $1 / 2$ & $92.5 \mathrm{~g}$ & $0.20 \mathrm{~g}$ & \\
\hline & plain yoghurt, $0 \%$ fat & $1 / 2$ & $26 \mathrm{~g}$ & $0.03 \mathrm{~g}$ & \\
\hline & MCT oil & 2 & $12 \mathrm{~mL}$ & - & \\
\hline $17: 30$ & apple & 1 & $109 \mathrm{~g}$ & $0.15 \mathrm{~g}$ & An apple between meals. \\
\hline \multirow{6}{*}{ 19:30 } & French baguette & 3 & $54 \mathrm{~g}$ & $0.87 \mathrm{~g}$ & \multirow{6}{*}{$\begin{array}{l}\text { Bake french baguette at about } 200 \text { degrees Celsius for } \\
1 \text { min, remove baguettes from oven, rub a clove of } \\
\text { garlic, add MCT oil, add ham and roast for about } 3 \text { min. } \\
\text { Pour yoghurt or ketchup over ready baguettes and } \\
\text { season to taste. Serve cherry tomatoes with baguettes. }\end{array}$} \\
\hline & turkey ham & $1 / 2$ & $30 \mathrm{~g}$ & $0.48 \mathrm{~g}$ & \\
\hline & plain yoghurt 0\% fat & $1 / 2$ & $26 \mathrm{~g}$ & $0.03 \mathrm{~g}$ & \\
\hline & ketchup & $1 / 4$ & $13.5 \mathrm{~g}$ & $0.10 \mathrm{~g}$ & \\
\hline & cherry tomatoes & $1 / 4$ & $83 \mathrm{~g}$ & $0.16 \mathrm{~g}$ & \\
\hline & MCT oil & 1 & $6 \mathrm{~mL}$ & - & \\
\hline 23:00 & corn starch & 3 & $42 \mathrm{~g}$ & - & $\begin{array}{l}3 \text { EE of corn starch mix with cold water (approx. } 150 \mathrm{~mL} \text { ) } \\
\text { and give before bedtime. }\end{array}$ \\
\hline & Sum & 30 & - & $11.2 \mathrm{~g}$ & \\
\hline
\end{tabular}

The structure of diet: 16\% energy from proteins, 60\% energy from carbohydrates, $24 \%$ energy from fats, $6.7 \%$ energy from LCT, including 3.8\% energy from EFAs (ALA + LA); $100 \mathrm{mg}$ of DHA. 
energy requirement in a patient with LCHADD should be increased depending on their physical activity.

\section{The scheme for preparing a menu using energy exchangers with LCT}

Below, the description shows the exact diet nutrition plan to propose a menu for a particular patient with LCHADD using energy exchangers with LCT.

Knowing the basic data of a patient with LCHADD, i.e. age, height, body weight and level of physical activity, the energy requirement should be determined using $\mathrm{Ta}$ bles 2-4. Example of patient data: a boy with LCHADD, 6 years of age, weighing $20.8 \mathrm{~kg}$, height of $120 \mathrm{~cm}$, moderate level of physical activity. The daily energy requirement calculated from Table 3 for a 6 year-old-boy was $1508 \mathrm{kcal}(\approx 1500 \mathrm{kcal})$.

The energy requirements of the patient converted to the energy exchangers and LCT content $(\mathrm{g} / \mathrm{d})$ should be read in Table 8. The energy exchangers given value for $1500 \mathrm{kcal}$ is $30 \mathrm{EE}$. Daily energy intake with LCT in the diet in LCHADD should not exceed $10 \%$ of the total energy intake and should be determined individually by the patient's doctor. The given value in Table 8 for $10 \%$ of energy with LCT equals $16.7 \mathrm{~g}$. This means that the LCT content in the diet should not exceed a sum of $16.7 \mathrm{~g}$ in a boy with LCHADD whose energy requirement equals $1500 \mathrm{kcal}$.

The intervals between meals and their number should be consulted with a doctor and a nutritionist (Table 1).

In some cases, as a night meal, a patient can be given raw corn starch prepared e.g. with cold water. The amount of corn starch depends on the weight and age of the patient. For a 6 -year-old patient, weighing $20.8 \mathrm{~kg}$, the starch content of the night meal is $42 \mathrm{~g}(3 \mathrm{EE})$, assuming $2 \mathrm{~g} / \mathrm{kg}$ of body mass/meal.

The next stage is preparing the menu using the blocks based on EE with the calculated LCT content. The number of portions from a given group of food products should be read in the food pyramid for LCHADD patients in Fig. 1. A one-day menu for the 6-year-old boy with LCHADD (30 EE) is described in the Table 11.

\section{Summary}

The presented method of composing a menu in LCHADD with 25 blocks with LCT allows the preparation of a menu for a sick child or an adult in a very fast and precise way. This method can prove to be effective in the hands of both the doctor and the nutritionist, dealing with the dietary therapy of inborn defects of metabolism, but above all it makes it easier for the patients themselves and their families to plan and precisely control the diet in LCHADD every day.

\section{References:}

1. Kompare M, Rizzo WB. Mitochondrial fatty-acid oxidation disorders. Semin Pedriatr Neurol. 2008;15:140-149.

2. Cichoż-Laż H. Patogeneza chorób wątroby związanych z ciążą. Ginekol Pol. 2010;81:613-617.

3. Van Hove JL, Kahler SG, Feezor MD, et al. Acylcarnitines in plasma and blood spots of patients with long-chain 3-hydroxyacyl-coenzyme A dehydrogenase deficiency. J Inherit Metab Dis. 2000;23:571-582.

4. Fronczyk A, Romanowska H, Majkowska L. Rzadkie przyczyny hipoglikemii u dorosłych - zaburzenia glukoneogenezy i zaburzenia $\beta$-oksydacji kwasów tłuszczowych. Pol Merk Lek. 2011;176:147-149.

5. Spiekerkoetter U, Lindner M, Santer R, et al. Treatment recommendations in long-chain fatty acid oxidation defects: Consensus from a workshop. J Inherit Metab Dis. 2009;32:498-505.

6. Ministerstwo Zdrowia. Program polityki zdrowotnej pt.: Program badań przesiewowych noworodków w Polsce na lata 2009-2014. Warszawa, 2009. http://www2.mz.gov.pl/wwwfiles/ma_struktura/ docs/przesiewy_06012010.pdf.

7. Piekutowska-Abramczuk D, Olsen RK, Wierzba J, et al. A comprehensive HADHA c.1528G $>$ C frequency study reveals high prevalance of long-chain 3-hydroxyacyl-CoA dehydrogenase deficiency in Poland. J Inherit Metab Dis. 2010;33:373-377.

8. Minister Zdrowia. Program polityki zdrowotnej. Program badań przesiewowych noworodków w Polsce na lata 2015 - 2018. Warszawa, 2015.http://www.mz.gov.pl/_data/assets/pdf_file/0004/27733/ aktualny-projekt-programu-przesiew-w-PDF-na-strone.pdf.

9. Scaglia F, Rohena LO. Long-chain acyl CoA dehydrogenase deficiency treatment \& management. 2014. http://emedicine.medscape.com/article/945857-treatment\#d8.

10. Kaluzny L, Szczepanik M, Siwinska-Mrozek Z, Borkowska-Klos M, Cichy W, Walkowiak J. Parenteral nutrition in patients with inborn errors of metabolism - a therapeutic problem. Eur Rev Med Pharmacol Sci. 2014;18:1579-1582.

11. Coran AG, Adzick NS, Krummel TM, Laberge JM, Shamberger RC, Caldamone AA. Pedriatric Surgery. $7^{\text {th }}$ ed. Elsevier Inc, Philadelphia: 2012.

12. Jarosz M. Normy żywienia dla populacji polskiej-nowelizacja. İZŻ, Warszawa 2012.

13. Gillingham MB, Connor WE, Matern $\mathrm{D}$, et al. Optimal dietary therapy of long-chain 3-hydroxyacyl-CoA dehydrogenase deficiency. Mol Genet Metab. 2003;79:114-123.

14. Human energy requirements. Report of a Joint FAO/WHO/UNU Expert Consultation. FAO Food and Nutrition Technical Report Series. Rome, 2004. http://www.fao.org/docrep/007/y5686e/y5686e00.htm

15. Gillingham MB, Purnell JQ, Jordan J, Standler D, Haqq AM, Harding CO. Effects of higher dietary protein intake on energy balance and metabolic control in children with long-chain 3-hydroxy acyl-CoA dehydrogenase (LCHAD) or trifunctional protein (TFP) deficiency. Mol Genet Metab. 2007;90:64-69.

16. Gillingham MB, Weleber RG, Neuringer M, et al. Effect of optimal dietary therapy upon visual function in children with long-chain 3-hydroxyacyl CoA dehydrogenase and trifunctional protein deficiency. Mol Genet Metab. 2005;86:124-135.

17. Behrend AM, Harding CO, Shoemaker JD, et al. Substrate oxidation \& cardiac performance during exercise in disorders of long chain fatty acid oxidation. Mol Genet Metab. 2012;105:110-115.

18. Kowalik A, Sykut-Cegielska J. Leczenie dietetyczne w deficycie dehydrogenazy 3-hydroksyacylo-CoA długołańcuchowych kwasów tłuszczowych (LCHADD). Pediatria. 2013;10:367-373.

19. Gillingham MB, Scott B, Elliott D, Harding CO. Metabolic control during exercise with and without medium-chain triglycerides (MCT) in children with long-chain 3-hydroxy acyl-CoA dehydrogenase (LCHAD) or trifunctional protein (TFP) deficiency. Mol Genet Metab. 2006;89:58-63.

20. Ulotka MCT Procal. http://www.vitaflousa.com/wp-content/ uploads/2013/07/MCT-Procal-A5-12036-5.7.12.pdf.

21. Szajewska $H$, Socha $P$, Horvath $A$, Rybak $A$, et al. Zasady żywienia zdrowych niemowląt. Zalecenia Polskiego Towarzystwa Gastroenetrologii, Hepatologii i Żywienia Dzieci. Standardy Medyczne. Pediatria. 2014;11:321-338.

22. EFSA Panel on Dietetic Products, Nutrition and Allergies. Scientific opinion on nutrient requirements and dietary intakes of infants and young children in the European Union. EFSA Journal. 2013;11:3408. 
23. German Nutrition Society, Austrian Nutrition Society, Swiss Society for Nutrition Research, Swiss Nutrition Association: Reference Values for Nutrient Intake (D-A-CH). 2000, Frankfurt am Main, Umschau/Braus.

24. Gillingham M, Van Calcar S, Ney D, Wolff J, Harding C. Dietary management of long-chain 3-hydroxyacyl-CoA dehydrogenase deficiency (LCHADD). A case report and survey. J Inherit Metab Dis. 1999;22:123-131.

25. Solis JO, Singh RH. Management of fatty acid oxidation disorders: A survey of current treatment strategies. J Am Diet Assoc. 2002;102:1800-1803.

26. Harding CO, Gillingham MB, van Calcar SC, Wolff JA, Verhoeve JN, Mills MD. Docosahexaenoic acid and retinal function in children with long-chain 3-hydroxyacyl-CoA dehydrogenase deficiency. $J$ Inherit Metab Dis. 1999;22:276-280.

27. Roe CR, Roe DS, Wallace M, Garritson B. Choice of oils for essential fat supplements can enhance production of abnormal metabolites in fat oxidation disorders. Mol Genet Metab. 2007;92:346-350.
28. Ulotka Lipistart. http://www.vitaflo.com.au/files/2012/05/LipistartData-Sheet.pdf.

29. Abdenur JE, Chamoles NA, Schenone $A B$, et al. Multiple acyl-CoA-dehydrogenase deficiency (MADD): Use of acylcarnitines and fatty acids to monitor the response to dietary treatment. Pediatr Res. 2001;50:61-66.

30. Sonneville K, Duggan C. Manual of pediatric nutrition. PMPH-USA Ltd, Shelton 2014, $5^{\text {th }}$ ed.

31. Kleinman RE, Goulet OJ, Mieli-Vergani G. Walker's Pediatric Gastrointestinal Disease: Physiology, Diagnosis, Management. Decker Inc, Ontario BC 2008, $5^{\text {th }}$ ed.

32. Kunachowicz H, Nadolna I, Przygoda B, Iwanow K. Tabele składu i wartości odżywczej żywności. Warszawa: PZWL; 2005.

33. Ziemlański Ś. Podstawy prawidłowego żywienia człowieka. Zalecenia żywieniowe dla ludności w Polsce. Warszawa: Instytut Danone; 1998.

34. Gawęcki J. Żywienie człowieka. Podstawy nauki o żywieniu. Warszawa: PWN; 2010. 